\title{
PERCEPTION OF BIG MUSIC FESTIVAL BY ITS PARTICIPANTS - CONTEXT OF EVENT SPONSORS' MARKETING ACTIVITIES
}

\begin{abstract}
Huge marketing events may be used by their sponsors to provide vast masses of people with extraordinary and memorable experiences that have a powerful impact on a brand image. Music festivals have a considerable potential in this respect. This paper demonstrates how participants of Pol'and'Rock Festival see this event in the marketing dimension and how they perceive activities performed by sponsors. The authors conducted survey research, the results of which showed that festival participants recognise and accept marketing activities carried out by the event organiser and sponsors. The majority of respondents are aware of the fact that they could not attend concerts free of charge without financial support provided by sponsors. The results of the research not only serve as a basis for further, in-depth scientific analyses, but also enable the festival organiser and its partners to gain knowledge of how to perform marketing activities in an effective manner.
\end{abstract}

Keywords: marketing, sponsoring, marketing events, big music festivals, Pol'and'Rock Festival.

\section{INTRODUCTION}

In the face of a huge mass of promotional information released on television, on the radio, in the press and on the Internet, contemporary enterprises seek effective solutions to reach both prospective and current customers in a direct way. One of the communication channels allowing for such close and memorable contact with a brand includes marketing events. They have the potential to create an extraordinary experience, use this experience to develop relationships with customers, link the brand to good causes, and build, change, reinforce brand image through association with the qualities of the event (Wood, 2009, p. 253). From among marketing events, those which are particularly useful for building an image of sponsors' brands may include music festivals, which are attended by people from distant locations of a country (and even from abroad) in order to have fun and

\footnotetext{
${ }^{1}$ Marcin Gębarowski, Associate Professor, College of Management Sciences and Quality, Institute of Quality and Product Management Sciences, Cracow University of Economics, ul. Rakowicka 27, 31-510 Cracow; e-mail: marcing.gebarowski@uek.krakow.pl (corresponding author). ORCID: 0000-0003-0722-3314.

2 Magdalena Majka, MSc., eng., former student, College of Management Sciences and Quality, Institute of Quality and Product Management Sciences, Cracow University of Economics, ul. Rakowicka 27, 31-510 Cracow; e-mail: magda2796@gmail.com. ORCID: 0000-0003-0353-6911.
} 
experience strong emotions, while sharing a sense of community with other music enthusiasts. Music festivals have increased rapidly since the 1990s. These events have seen a surge in both size and numbers leading to a more business-oriented festival management. Thus, the knowledge regarding the music festivals deserves attention more explicitly than ever before (Kinnunen, Luonila, Honkanen, 2019).

Nevertheless, scholars' focus on huge music events is incommensurate with the paramount importance they may have to contemporary promotional activities. This observation refers specifically to the Polish literature on the subject. Hence this paper fills that gap to a certain extent - as regards the perception of event sponsors' brands. This publication - based on research conducted by the authors - aims to present how participants of Pol'and'Rock Festival see the event in the marketing dimension and how they perceive activities carried out by its sponsors. Empirical material was collected by means of a survey covering participants of Pol'and'Rock Festival (Poland's biggest music event and one of the greatest events all around the world).

\section{MARKETING EVENT AS SPACE FOR BUILDING SPONSORS' BRAND IMAGE}

A marketing event constitutes a promotional undertaking which is a communicative situation created with a view to attaining specific objectives - brought about at a particular place and time by an organiser and its partners/sponsors. The essence of such events is that they are unique and take the most attractive (which in practice means: novel) form (Jaworowicz, Jaworowicz, 201). A marketing event enables brands involved in creating it to appeal to all senses of participants and provide them with experiences they expect to enjoy. To this end, diversified, powerful means of expression are employed - such as lighting, music, stage special effects. A fundamental characteristic of event marketing is developing and strengthening emotional ties between promoted brands and customers. All events constitute an interactive tool for communication between companies and various groups of recipients of marketing activities from their environment (Gębarowski, 2007).

Contemporary marketing events take diversified forms. These include concerts, congresses, exhibitions, sports events, political rallies, happenings, open days and many more. These are not only mass events, but also smaller undertakings (e.g. road shows, presentations of new products) and they are not always held in an open space (like fashion shows, barman shows - so-called flairs). A given event becomes a marketing event when it is accompanied by a spectacular setting creating a 'wow' customer experience. During marketing events, one can observe a classic marketing communication process including such components as: sender, encoding, message, decoding, receiver; but also: response, feedback, noise and context. Such communication happens "here and now" ('live') and appeals to all receivers' senses. Key questions concerning that process are: who says? what does he/she say? through which channel does he/she say? to whom does he/she say? what is the outcome? (Dobek-Ostrowska, 1999; Jaworowicz, Jaworowicz, 2016). During events, the role of senders is occupied by sponsors (together with the organiser), receivers are prospective and current clients, whereas desired response includes, first and foremost, a permanent change in the perception of brands. The most important component of the process are senders, who initiate, plan and manage the event (which includes setting objectives, choosing means designed to attain them, as well as measuring effects obtained). 
The scholarly literature defines categories of biggest marketing events that enjoy considerable popularity - both among those who participate in them personally and people watching media coverage. M. Müller developed a multidimensional, point-based classification scheme of large events according to size, distinguishing between major events, mega-events and giga-events (table 1). According to the author, in order to qualify as a major event, an event needs to have an L size on at least one dimension (Müller, 2015). Pol'and'Rock Festival meets the requirements which are necessary for this music festival to be categorised as a major event (the distinguishing features of Pol'and'Rock Festival are mentioned in the following chapter $)^{3}$.

Table 1. Scoring matrix for event classes according to size

\begin{tabular}{|l|c|c|c|c|}
\hline \multicolumn{1}{|c|}{ Size } & $\begin{array}{c}\text { Visitor attractiveness } \\
\text { Number of tickets } \\
\text { sold }\end{array}$ & $\begin{array}{c}\text { Mediated reach } \\
\text { Value of } \\
\text { broadcast rights }\end{array}$ & $\begin{array}{c}\text { Cost } \\
\text { Total cost }\end{array}$ & $\begin{array}{c}\text { Transformation } \\
\text { Capital } \\
\text { investment }\end{array}$ \\
\hline XXL (3 points) & $>3$ million & $>$ USD 2 billion & $>$ USD 10 billion & $>$ USD 10 billion \\
\hline XL (2 points) & $>1$ million & $>$ USD 1 billion & $>$ USD 5 billion & $>$ USD 5 billion \\
\hline L (1 point) & $>0.5$ million & $>$ USD 0.1 billion & $>$ USD 1 billion & $>$ USD 1 billion \\
\hline Giga-event & \multicolumn{5}{|c|}{$\begin{array}{c}\text { 11-12 points total } \\
\text { Mega-event } \\
\text { Major event }\end{array}$} \\
\hline
\end{tabular}

Source: (Müller, 2015).

Research performed so far has confirmed that the promotion of a brand through the sponsoring of marketing events (including also music festivals) may effectively shape a brand image - increase brand equity and brand involvement (e.g. Close, Finney, Lacey, Sneath, 2006; Martensen, Grønholdt, 2008; Rowley, Williams, 2008; Zarantonello, Schmitt, 2013). However, this requires the understanding of the uniqueness of respective events and the proper management of them. An important issue concerns sponsor-event congruence, because when event and brand are matched on either an image or functional basis the transfer process is enhanced (Gwinner, Eaton, 1999; Hutabarat, Gayatri, 2014). It must be emphasised that music festivals are unique marketing events and - apart from advantages associated with branding - bring additional intangible benefits, particularly fostering an appreciation of a music genre, increasing purchasing of music, and boosting music tourism (Kruger, Saayman, 2019). In addition to cultural influences, music festivals have also economic, social and environmental impacts (Andersson, Armbrecht, Lundberg, 2012). Music festivals exert also substantial influence on local communities. Increasingly those events have been promoted and created as tourist attractions (Andersson, Getz, 2008). Moreover, they may become a familiar and unremarkable - or even valued - part of residents' live (Han, Wang, Zheng, Zhang, 2017).

It must be noted that shaping an image of a brand among customers is only one of the objectives that marketing communication attempts to achieve by means of marketing events. Other important aspects of organising or sponsoring such events include: encouraging engagement among employees involved in sales and promotion (e.g. team

\footnotetext{
${ }^{3}$ The authors of this paper decided to refer to Pol'and'Rock Festival as a "big event" instead of
} a "major event". 
building parties for sales representatives); popularising direct product purchases among customers (tasting, handing samples out, demonstrations, direct sales at booths); forging partnership ties with recipients (e.g. retailers, key wholesalers); consolidation with local communities (e.g. events organised for citizens of a specific regions or city) (Mruk, 2004). Events are thus a multifunctional form of direct communication which in a contemporary world of experience economy should be an important area of companies' marketing activity.

\section{POL'AND'ROCK FESTIVAL - ONE OF WORLD'S BIGGEST MUSIC EVENTS}

Pol'and'Rock Festival is Poland's biggest music event and one of the greatest events all around the world. It dates back to 1995, when it was organised for the first time by the Great Orchestra of Christmas Charity Foundation (Polish: Fundacja Wielka Orkiestra Światecznej Pomocy - WOŚP). This is the biggest non-profit, charity organisation in Poland, which supports public healthcare by purchasing state-of-the-art equipment for Polish hospitals and clinics. The leader of this organisation is a well-known journalist and social campaigner - Jerzy Owsiak, also spiritus movens of the festival. This event is gratitude towards around 120,000 volunteers of the Great Orchestra of Christmas Charity, who every year in January raise funds on the streets of Polish cities and villages to support hospitals treating children and elderly people. The festival is also gratitude to people putting money in special collection boxes (in 2020, over PLN 186 million - an equivalent of around $\$ 50$ million - was raised). Between 1995 and 2017, the event was held under the name Woodstock Station (in Polish: Przystanek Woodstock), which was a reference to the legendary American rock festival and a TV series popular in the 1990's Northern Exposure (in Polish: Przystanek Alaska). However, for legal reasons (the licence expired), after more than two decades of organising the event, its name had to be changed - in 2018, the name Pol'and'Rock Festival came into use. Since 2004, the event has been held in Kostrzyn nad Odrą - a city located at the border between Poland and Germany. Previously, Woodstock Station was hosted in Czymanowo, Szczecin-Dąbie, Żary and Lębork. From the very beginning, the festival's motto has been "Love. Friendship. Music".

Preparing Pol'and'Rock Festival requires great organisational and financial commitment. Therefore the Great Orchestra of Christmas Charity Foundation relies on support from many entities, including official sponsors and partners - such as media, music, medical, technological and Internet partners. Because of several dozen of sponsors and partners, participation in the festival is for free, and its programme contains many accompanying events.

The cost of organising Pol'and'Rock Festival is estimated at approx. PLN 10 million (i.e. around USD 2.65 million). The event is financed with money collected from sponsors and donors. Last editions of the festival (hosted for three days at the beginning of August) were attended by around 750,000 people. In 2019, there were more than 60 artists, who performed on five stages ${ }^{4}$. Throughout its twenty-six editions, the festival has featured almost all famous Polish singers and bands, as well as a lot of big names from abroad (The Prodigy, Ugly Kid Joe, Within Temptation, Judas Priest, Die Toten Hosen, Shaggy and many more). Although the main music genre includes rock, visitors may also enjoy other sounds ranging from folk and reggae, through metal and rap, to classical and electronic

\footnotetext{
${ }^{4}$ In 2020, due to the COVID-19 pandemic, Pol'and'Rock Festival took an exceptional form -
} concerts were hosted in a television studio and broadcast on line. 
music. Obscure bands go for auditions held by the Foundation, and those which pass, can perform for the festival audience. Apart from music concerts staged as part of the festival, there is also The Academy of Fine Arts (Polish: Akademia Sztuk Przepięknych), that is to say, meetings with famous people representing the world of politics, media, culture and arts. The festival also enables the promotion (e.g. by workshops) of many non-governmental organisations and other institutions involved in human rights, health, education, personal development, religions, ecology, culture, sport, social integration (during the last edition of the festival, these were: Amnesty International, Greenpeace Poland, Polish Humanitarian Action, The Office of Commissioner for Human Rights, Vegetarians International Voice For Animals - VIVA, The State Agency for the Prevention of Alcohol-Related Problems, and many more).

Pol'and'Rock Festival (formerly Woodstock Station) has been the focus of attention of very few researchers. Scholarly publications released so far examine the following aspects of this event: safety of mass event (Kaak, 2016; Moch, 2017; Kuglasz, 2019), recycling of waste (Rochowicz, 2012), manifestations of ritual process and the identity of event community (Lesicki, 2015; Żyła, 2017), the reasons behind participation (Rerek, Dłużewska, 2016), satisfaction and loyalty of participants - in the context of tourist product component (Nowacki, 2014), aesthetic reflections - event as a cultural performance (Węcławiak, 2016). Woodstock Station also received a detailed coverage, however, only in general terms (Chmielewska-Szlajfer, 2019). From the perspective of marketing, one should highlight - as an interesting fact - that participants of the festival took part in medical research - concerning the digestive health and abdominal pain (Skonieczna-Żydecka, Maciejewska, Czerwińska-Rogowska, Ryterska et al., 2018; Skonieczna-Żydecka, Stachowska, Maciejewska, Ryterska et al., 2018; Stachowska, Maciejewska, Ryterska, Baszuk et al., 2018). Furthermore, an article on medical security of the event was published (Hajduczenia, Kleszczyński, Braksator, 2011). There was a successful defence of a $\mathrm{PhD}$ thesis called "Rock Ethos of Young Generation on Example of Woodstock Station and in Context of Other Activities of Great Orchestra of Christmas Charity Foundation"5. Moreover, Polish students wrote many diploma theses relating to the festival (many of them were defended in the Faculty of Philosophy and the Faculty of Management and Social Communication at the Jagiellonian University). Hence a literature review reveals that publishing the results of the research into the sponsoring of Pol'and'Rock Festival fills the existing niche, as there are no scholarly papers that deal with the issue in question.

\section{METHODOLOGY AND CHARACTERISTICS OF RESEARCH SAMPLE}

An Internet survey was used as a research method ${ }^{6}$. Respondents were chosen purposely, and the basic criterion for inviting a person for the research was their participation in Pol'and'Rock Festival several times. The questionnaire comprised closed-ended and semiopen questions, as well as one open-ended question. Respondent profile was described by means of demographics questions. The research covered 770 people who participated in Poland's biggest music festival at least once.

5 The PhD thesis was defended in 2012 in the Institute of Cultural Studies at the University of Wroclaw. The dissertation was authored by J. Teodorczyk, and her supervisor was prof. dr. hab. M. Kocur.

${ }^{6}$ The reason behind choosing this method was that respondents were spread over a vast area and that there was the COVID-19 pandemic (and related restrictions on face-to-face meetings). 
The following research problem was framed as part of exploration: how Pol'and'Rock Festival is perceived by event participants in the context of actions taken with a view to building a sponsors' brand image. In view of such a question - and also based on many years' observations of the co-author of this paper, who participated in the music festival several times - the following hypotheses were put forward:

- $\mathrm{H}_{1}$ : Participants of Pol'and'Rock Festival discern and accept marketing activities performed by the organiser and sponsors of the event;

- $\mathrm{H}_{2}$ : Sponsors of Pol'and'Rock Festival are seen in a positive light by event participants;

- $\mathrm{H}_{3}$ : Pol'and'Rock Festival is considered by its participants to be an integrated product in terms of marketing.

Empirical data was gathered between April and May 2020. Table 2 shows the structure of a researched sample. Out of all respondents, the majority were women, people aged $18-25$, those who received secondary education and living in cities with over 100,000 residents and professionally active.

Table 2. Characteristics of research sample

\begin{tabular}{|c|c|c|}
\hline \multirow{2}{*}{ gender } & women & $67.8 \%$ \\
\hline & men & $32.2 \%$ \\
\hline \multirow{7}{*}{ age } & under 18 years & $3.2 \%$ \\
\hline & $18-25$ years & $50.1 \%$ \\
\hline & $26-35$ years & $34.4 \%$ \\
\hline & $36-45$ years & $9.6 \%$ \\
\hline & $46-55$ years & $1.7 \%$ \\
\hline & $56-65$ years & $0.7 \%$ \\
\hline & over 65 years & $0.3 \%$ \\
\hline \multirow{5}{*}{ education } & primary school & $1.3 \%$ \\
\hline & junior secondary school (gimnazjum) & $3.6 \%$ \\
\hline & basic vocational school & $4.3 \%$ \\
\hline & secondary school & $50.5 \%$ \\
\hline & higher education & $40.3 \%$ \\
\hline \multirow{3}{*}{ place of residence } & village & $18.7 \%$ \\
\hline & city with under 100,000 residents & $32.9 \%$ \\
\hline & city with over 100,000 residents & $48.4 \%$ \\
\hline \multirow{6}{*}{ professional status } & students & $10.6 \%$ \\
\hline & undergraduates / postgraduates & $11.7 \%$ \\
\hline & undergraduates / postgraduates and employed & $16.6 \%$ \\
\hline & employed & $56.4 \%$ \\
\hline & unemployed & $4.2 \%$ \\
\hline & pensioner & $0.5 \%$ \\
\hline
\end{tabular}

Source: own elaboration. 
Data obtained from the respondents were aggregated, processed and then analysed. This delivered results based on which the hypotheses were verified and which revealed the assessment of Pol'and'Rock Festival participants - concerning both the marketing dimension of the entire event and sponsors' branding activity.

\section{RESULTS}

As regards the evaluation of aspects attracting researchers' attention, the respondents' experience related to participation in Pol'and'Rock Festival was of key importance. The fact that a person being surveyed had observed this event many times was enough to assume that they would give fair answers to questions. Half of the respondents attended the festival four or more times. Those who participated in the event once, two or three times accounted for approx. $16 \%$ in each of these groups (table 3 ).

Table 3. The percentage breakdown of answers to the question: "How many times have you participated in Pol'and'Rock Festival (Woodstock)?"

\begin{tabular}{|l|c|}
\hline once & $16.6 \%$ \\
\hline two times & $16.0 \%$ \\
\hline three times & $16.9 \%$ \\
\hline four times & $8.8 \%$ \\
\hline more than four times & $41.7 \%$ \\
\hline
\end{tabular}

Source: own elaboration.

Almost all people - as many as $96.5 \%$ - who were surveyed, declared that they would come to Pol'and'Rock Festival in the future. Only $0.4 \%$ of respondents did not intend to participate in the event, whereas $3.1 \%$ had no opinion on that matter (table 4 ).

Table 4. The percentage breakdown of answers to the question: "Will you attend Pol'and'Rock Festival again?"

\begin{tabular}{|l|c|}
\hline yes & $96.5 \%$ \\
\hline no & $0.4 \%$ \\
\hline it is difficult to say & $3.1 \%$ \\
\hline
\end{tabular}

Source: own elaboration.

Results obtained showed that overwhelming majority $(87.4 \%)$ of respondents were aware of marketing activities performed by the festival organiser and sponsors. Whereas no such activity was discerned by only $1.3 \%$ of those surveyed, and $11.3 \%$ was not able to adopt any position on that issue (table 5).

Table 5. The percentage breakdown of answers to the question: "Are you aware of marketing activities taken by the organiser and sponsors of Pol'and'Rock Festival?"

\begin{tabular}{|l|c|}
\hline yes & $87.4 \%$ \\
\hline no & $1.3 \%$ \\
\hline it is difficult to say & $11.3 \%$ \\
\hline
\end{tabular}

Source: own elaboration. 
Majority (69.9\%) of Pol'and'Rock Festival participants being surveyed were aware of the fact that without sponsors and activity they carried out during the event, participation in concerts would not be free of charge. Only $7.4 \%$ of respondents were convinced that admission to the festival could be possible for free without sponsors being involved, while $22.7 \%$ were not able to adopt any position on that issue (table 6). Therefore the first hypothesis - suggesting that participants of festival discern and accept marketing activities performed by the organiser and sponsors of the event - has proved to be correct.

Table 6. The percentage breakdown of answers to the question: "Do you think that Pol'and'Rock Festival could be for free in the form known today if sponsors' activity was no longer carried out?"

\begin{tabular}{|l|c|}
\hline yes & $7.4 \%$ \\
\hline no & $69.9 \%$ \\
\hline it is difficult to say & $22.7 \%$ \\
\hline
\end{tabular}

Source: own elaboration.

Survey respondents were asked what marketing activities they experienced during Pol'and'Rock Festival (table 7). Most frequently, the answer referred to the limited series of products with a logo of the event $(87.0 \%)$, competitions/quizzes/games $(78.1 \%)$ and freebies with the festival logo handed out to visitors $(76.1 \%)$. Moreover, the following answers were given: the promotion of charitable organisations $(67.7 \%)$, the availability of footage from the event $(56.9 \%)$, the samples of sponsors' products and leaflets handed out to festival goers $(47.0 \%$ and $46.1 \%$ respectively), price discounts on sponsors' products $(24.2 \%)$.

Table 7. Marketing activities which the respondents experienced during Pol'and'Rock Festival?

\begin{tabular}{|l|l|}
\hline availability of limited series of products with the logo of Pol'and'Rock Festival & $87.0 \%$ \\
\hline competitions/quizzes/games & $78.1 \%$ \\
\hline freebies with the Pol'and'Rock Festival logo handed out to visitors & $76.1 \%$ \\
\hline promotion of charitable organisations & $67.7 \%$ \\
\hline availability of footage from Pol'and'Rock Festival & $56.9 \%$ \\
\hline product samples handed out to festival goers & $47.0 \%$ \\
\hline leaflets handed out to festival goers & $46.1 \%$ \\
\hline price discounts & $24.2 \%$ \\
\hline
\end{tabular}

Source: own elaboration.

The overwhelming majority of respondents $(86.2 \%)$ were of the opinion that the sponsorship of Pol'and'Rock Festival had a positive impact on the image of brands supporting the event. On the other hand, $6.5 \%$ of survey respondents did not see such a correlation, whereas $7.3 \%$ of those polled had no opinion on that matter (table 8). The second hypothesis - concerning the fact that the sponsors of Pol'and'Rock Festival are perceived by festival-goers in a positive way - has proved to be true. 
Table 8. The percentage breakdown of answers to the question: "Do you think that the sponsorship of Pol'and'Rock Festival has a positive bearing on the image of brands supporting the event?"

\begin{tabular}{|l|c|}
\hline yes & $86.2 \%$ \\
\hline no & $6.5 \%$ \\
\hline it is difficult to say & $7.3 \%$ \\
\hline
\end{tabular}

Source: own elaboration.

As many as $81.3 \%$ of respondents indicated that zones organised by the sponsors of Pol'and'Rock Festival increased the attractiveness of the whole event, while $8.4 \%$ of those surveyed answered to the contrary, and every tenth person had no opinion on that matter (table 9).

Table 9. The percentage breakdown of answers to the question: "Do you think that entertainment zones arranged by sponsors of Pol'and'Rock Festival increase its attractiveness?"

\begin{tabular}{|l|c|}
\hline yes & $81.3 \%$ \\
\hline no & $8.4 \%$ \\
\hline it is difficult to say & $10.3 \%$ \\
\hline
\end{tabular}

Source: own elaboration.

Respondents pointed out that they were keen on attractions provided by sponsors of Pol'and'Rock Festival (table 10). Nearly 60\% of festival goers always, very often or rather often took part in attractions offered by the owners of various brands.

Table 10. The percentage breakdown of answers to the question: "How often do you take part in attractions provided by sponsors of Pol'and'Rock Festival (e.g. Play, Allegro, Lidl, mBank, Mastercard, Coca-Cola, Red Bull)?"

\begin{tabular}{|l|c|}
\hline always & $15.6 \%$ \\
\hline very often & $19.6 \%$ \\
\hline rather often & $24.3 \%$ \\
\hline neither often nor rarely & $24.2 \%$ \\
\hline rather rarely & $10.6 \%$ \\
\hline very rarely & $4.0 \%$ \\
\hline never & $1.7 \%$ \\
\hline
\end{tabular}

Source: own elaboration.

The survey questionnaire included a question which was asked to find out how important selected marketing activities performed by sponsors during the last edition of the event were for respondents. They responded that what they valued most was: the possibility of charging up their mobile phones in the Play's zone, the possibility of purchasing t-shirts and promotional items in SiemaShop, reusable cups offered in the Lech's zone. On the other hand, according to festival goers, the following were of marginal relevance: a free Internet 
and free calls package offered by Play for the duration of the event; the possibility of collecting special stamps with the Pol'and'Rock Festival theme (which allowed visitors to send postcards promoting Lubusz Voivodeship to any location in Poland free of charge); an opportunity for shooting a photograph with friends with a $\mathrm{RICOH}$ photo camera (table 11).

Table 11. The percentage breakdown of answers to the question: "How relevant are the following sponsors' activities to you? (1 - the least relevant; 5 - the most relevant)?"

\begin{tabular}{|l|c|c|c|c|c|}
\cline { 3 - 6 } \multicolumn{1}{l|}{} & 1 & 2 & 3 & 4 & 5 \\
\hline $\begin{array}{l}\text { possibility of enjoying a "Big Wheel" ride in the } \\
\text { Allegro's zone }\end{array}$ & $20.1 \%$ & $17.8 \%$ & $24.7 \%$ & $18.6 \%$ & $18.8 \%$ \\
\hline $\begin{array}{l}\text { charging up the mobile phone in the Play's zone for } \\
\text { free }\end{array}$ & $10.7 \%$ & $11.2 \%$ & $13.5 \%$ & $13.8 \%$ & $50.8 \%$ \\
\hline $\begin{array}{l}\text { free internet and free calls package (for four days) } \\
\text { offered by Play }\end{array}$ & $29.6 \%$ & $16.0 \%$ & $16.9 \%$ & $12.6 \%$ & $24.9 \%$ \\
\hline rest and relaxation in the Lidl's zone & $15.7 \%$ & $18.2 \%$ & $23.6 \%$ & $22.9 \%$ & $19.6 \%$ \\
\hline $\begin{array}{l}\text { possibility of collecting special stamps with the } \\
\text { Pol'and'Rock Festival theme and sending postcards } \\
\text { prepared by Lubusz Voivodeship) for free }\end{array}$ & $29.3 \%$ & $17.5 \%$ & $19.5 \%$ & $16.3 \%$ & $17.4 \%$ \\
\hline $\begin{array}{l}\text { possibility of buying t-shirts and promotional items in } \\
\text { SiemaShop }\end{array}$ & $2.3 \%$ & $4.4 \%$ & $13.0 \%$ & $16.7 \%$ & $63.6 \%$ \\
\hline reusable cups offered in the Lech's zone & $4.1 \%$ & $6.7 \%$ & $14.7 \%$ & $16.4 \%$ & $58.1 \%$ \\
\hline $\begin{array}{l}\text { opportunity for shooting a photograph with friends } \\
\text { with a RICOH photo camera }\end{array}$ & $23.9 \%$ & $20.6 \%$ & $21.1 \%$ & $16.2 \%$ & $18.2 \%$ \\
\hline possibility of buying footage recorded by KręciotaTV & $17.2 \%$ & $18.3 \%$ & $23.6 \%$ & $16.8 \%$ & $24.1 \%$ \\
\hline
\end{tabular}

Source: own elaboration.

More than $70 \%$ of respondents admitted that Pol'and'Rock Festival was an integrated offer. Only $6.4 \%$ of those polled responded differently. Every tenth person was not convinced whether the event constituted a coherent product in terms of marketing. Also, every tenth person had no opinion on that matter (table 12). Hence these results corroborate the last hypothesis.

Table 12. The percentage breakdown of answers to the question: "Do you think that Pol'and'Rock Festival is an integrated (comprehensive) product in terms of marketing?"

\begin{tabular}{|l|c|}
\hline yes & $32.7 \%$ \\
\hline rather yes & $39.0 \%$ \\
\hline neither 'yes' nor 'no' & $11.6 \%$ \\
\hline rather no & $2.9 \%$ \\
\hline no & $3.5 \%$ \\
\hline it is difficult to say & $10.3 \%$ \\
\hline
\end{tabular}

Source: own elaboration.

When answering the open-ended question, respondents pointed out that marketing activities carried out by sponsors during the event were appropriate. Nevertheless, apart 
from these opinions, there were also some dissenting voices relating to the Play's zone (a mobile network brand), which provided an atmosphere differing from the Pol'and'Rock Festival's climate. There was too loud and music emanating from the Small Stage and the Big Stage was drowned out. Moreover, the music genre offered by Play was of a different nature than rock concerts performed on both stages. This created the negative perception of this brand. Some people, when answering the open-ended question, stated that such sponsors' activities made the festival commercial and therefore every year it is attended by more and more "casual" visitors. However, only very few respondents asserted that sponsors and their activity diminished the attractiveness of this event. Marketing activities which are not aggressive, but at the same time are innovatory, are acceptable by people arriving at Pol'and'Rock Festival every year. Furthermore, some of those surveyed were of the opinion that sponsors' TV commercials featuring information about the festival or presenting what Jurek Owsiak (the main organiser) was saying had a positive bearing on the perception of the festival and effectively encouraged people to attend it. Moreover, as regards the values it promotes, such as: love, friendship, music, tolerance and concern over the natural environment, the event was seen by respondents in positive terms. They also emphasised that a unique feature of Pol'and'Rock Festival was that it could be attended free of charge, but at the same time, was perfectly organised and safe (despite considerable number of people participating in it).

\section{CONCLUSIONS}

Pol'and'Rock Festival is an exceptional event, which every year is attended by hundreds of thousands of people - not only from Poland, but also from many other countries. Even though the event has considerable potential for the promotion of sponsors' brands, so far, there have been no academic publications presenting the results of research exploring this issue - the results which, in practical terms, could be useful for both the event organiser and sponsors, and from the scientific point of view, could provide an introduction to more in-depth analyses.

This paper releases the results of a survey which covered people participating in Pol'and'Rock Festival. An overall score that the event received from respondents was very high, as almost all of them declared their participation in future editions of the festival. This provides evidence that festival goers' expectations regarding entertainment and building social relationships have been met, and demonstrates that they derived deep satisfaction from participating in the event as direct observers.

All research hypotheses have been proved. It was found that participants of Pol'and'Rock Festival discern and accept marketing activities performed by the organiser and sponsors. The majority of people arriving at Kostrzyn nad Odra are aware of the fact that admission to concerts would not be free if there was no support from brands using for their own marketing purposes - the area where hundreds of thousands of people enjoy their time. Furthermore, respondents declared that sponsors were seen by festival goers in positive terms, and the event itself was an integrated (coherent) product from the marketing point of view. According to respondents, in most cases (during the last edition the exception to the rule was Play), marketing activity was tailored to the festival climate - e.g. Lidl, a chain store brand, sold in its "field" shop, which was erected for the duration of the festival, products suitable for the needs of concert audience at attractive prices. Respondents noticed many marketing activities that were taken both by the organiser alone (e.g. the sale 
of products with the logo of the event) and its partners (e.g. product samples handed out to festival goers). Moreover, according to survey respondents, offerings provided in sponsors' zones (among other things, the possibility of charging up their mobile phones for free) are of relevance to them and increase the attractiveness of Pol'and'Rock Festival. Such zones have a powerful effect on a sponsors' brand image, as they offer entertainment, are a place of rest and relaxation and enable festival goers to integrate with each other. Every person can enter sponsors' zones free of charge and spend time before concerts, which start in the afternoon.

Results obtained by the authors revealed that the organiser of Pol'and'Rock Festival managed to create an event which has the broad masses of loyal followers. An exceptional atmosphere of the festival stems from its professional management and a perfect combination of non-commercial aspects (the form of gratitude to volunteers and donors of the Great Orchestra of Christmas Charity Foundation, free admission) and an indispensable commercial dimension (the activity of many sponsors which provide financial support for the organisation of such a huge event). The research results showed as a key managerial implication - a need for sponsors' activities being continuously adapted to the exceptional festival atmosphere encapsulated in a slogan "Love. Friendship. Music". As already mentioned, the survey dealt with the issue which has been given no coverage in scholarly literature yet. Hence the research was innovatory, and therefore general in nature. In further explorations, researchers should - taking into consideration bigger samples examine in detail the determinants of the event sponsorship (inter alia, investigate the congruence of the festival and sponsors).

Ever-changing needs of contemporary customers, who to a greater and greater extent expect brands to take active promotional activities, appealing strongly to all their senses, induce companies to use experience marketing more broadly. In this context, special significance is assumed by the sponsorship of big concerts (such as Pol'and'Rock Festival), which gives an opportunity for reaching many people directly - amidst the atmosphere of entertainment, with deep emotional commitment. By performing diversified activities in the place where such events are organised, sponsors seize an excellent opportunity to deliver meaningful and memorable experiences. It is important, however, that marketing activities taken are innovatory, on the one hand, and correspond to the nature of the festival (an open-air event, the atmosphere of fun and peace, rock music), on the other. As a matter of fact, sponsors' activity not only supports specific brands, but also contributes to creating an image of Pol'and'Rock Festival - one of the world's biggest music festivals.

\section{REFERENCES}

Andersson, T.D., Armbrecht, J., Lundberg, E. (2012). Estimating use and non-use values of a music festival. "Scandinavian Journal of Hospitality and Tourism", Vol. 12, No. 3. DOI: 10.1080/15022250.2012.725276.

Andersson, T.D., Getz, D. (2008). Stakeholder management strategies of festivals. “Journal of Convention \& Event Tourism”, Vol. 9, No. 3. DOI: 10.1080/15470140802323801.

Chmielewska-Szlajfer, H. (2019). Woodstock Station Festival: Practicing Recognition. Ordinary Celebrations [in:] Chmielewska-Szlajfer, H., Reshaping Poland's Community after Communism, Cham: Palgrave Macmillan. DOI: /10.1007/978-3-319-78735-0. 
Close, A.G., Finney, R.Z., Lacey, R.Z., Sneath, J.Z. (2006). Engaging the consumer through event marketing: Linking attendees with the sponsor, community, and brand. "Journal of Advertising Research", Vol. 46, Iss. 4.

Dobek-Ostrowska, B. (1999). Podstawy komunikowania społecznego. Wrocław: Wydawnictwo Astrum.

Gębarowski, M. (2007). Nowoczesne formy promocji. Rzeszów: Oficyna Wydawnicza Politechniki Rzeszowskiej.

Gwinner, K.P., Eaton, J. (1999). Building brand image through event sponsorship: The role of image transfer. "Journal of Advertising", Vol. 28, Iss. 4. DOI: 10.1080/00913367.1999. 10673595.

Hajduczenia, J., Kleszczyński, J., Braksator, M. (2011). Przystanek Woodstock 2009 and 2010 - danger to life and health and medical security of mass event. "Wiadomosci Lekarskie", Vol. 64, No. 2.

Han, J., Wang, W., Zheng, Ch., Zhang, J. (2017). Host perceptions of music festival impacts: time and space matter?. "Asia Pacific Journal of Tourism Research", Vol. 22, No. 11. DOI: 10.1080/10941665.2017.1374986.

Hutabarat, P., Gayatri, G. (2014). The influence of sponsor-event congruence in sponsorship of music festival. "South East Asian Journal of Management", Vol. 8, No. 1.

Jaworowicz, P., Jaworowicz, M. (2016). Event marketing $w$ zintegrowanej komunikacji marketingowej. Warszawa: Difin.

Kaak, W. (2016). Bezpieczeństwo imprez masowych. Przystanek Woodstock - praktyczne aspekty zabezpieczenia. "Studia Administracji i Bezpieczeństwa”, $\mathrm{nr} 1$.

Kinnunen, M., Luonila, M., Honkanen, A. (2019). Segmentation of music festival attendees. "Scandinavian Journal of Hospitality and Tourism", Vol. 19, Iss. 3. DOI: 10.1080/15022250. 2018.1519459.

Kruger, M., Saayman, M. (2019). 'All that jazz': the relationship between music festival visitors' motives and behavioural intentions. "Current Issues in Tourism", Vol. 22, No. 19. DOI: 10.1080/13683500.2018.1451496.

Kuglasz, J. (2019). Bezpieczeństwo Przystanku Woodstock w odbiorze jego uczestników [in:] Cieślikowska, M., Szostakowski, M., eds., Warsztaty badawcze doktorantów. Między teoria a praktyka metodologiczna. Warszawa: Wydawnictwo Akademii Pedagogiki Specjalnej.

Lesicki, T. (2015). Proces rytualny $i$ świat wyobrażony na festiwalach muzycznych. "Ars Educandi”, nr 12. DOI: 10.26881/ae.2015.12.10.

Martensen, A., Grønholdt, L. (2008). How events work: understanding consumer responses to event marketing. "Innovative Marketing", Vol. 4, Iss. 4.

Moch, M. (2017). Przystanek Woodstock - najbezpieczniejsza impreza masowa w Polsce?. "Studia Administracji i Bezpieczeństwa", $\mathrm{nr} 2$.

Mruk, H., ed. (2004). Komunikowanie się w biznesie. Warszawa: Polskie Wydawnictwo Ekonomiczne.

Müller, M. (2015). What makes an event a mega-event? Definitions and sizes. "Leisure Studies”, Vol. 34, No. 6. DOI: 10.1080/02614367.2014.993333.

Nowacki, M. (2014). Przystanek Woodstock jako produkt turystyczny: jakość festiwalu a zadowolenie i lojalność uczestników [in:] Krakowiak, B., Stasiak, A. eds., Kultura i turystyka - w kręgu wydarzeń. Łódź: Regionalna Organizacja Turystyczna Województwa Łódzkiego. 
Rerek, M., Dłużewska, A. (2016). Czy muzyka ma znaczenie? Powody uczestnictwa w koncertach jednodniowych i festiwalach muzycznych. "Geography and Tourism”, Vol. 4, No. 1. DOI: $10.5281 /$ zenodo.56743.

Rochowicz, M., (2012). Recyklingowo na Woodstock. "Przegląd Papierniczy”, nr 8.

Rowley, J., Williams, C. (2008). The impact of brand sponsorship of music festivals. "Marketing Intelligence \& Planning”, Vol. 26, No. 7. DOI: 10.1108/02634500810916717.

Skonieczna-Żydecka, K., Maciejewska, D., Czerwińska-Rogowska, M., Ryterska, K, Palma, J., Stachowska, Z., Stachowski, A., Gudan, A., Mruk, H., Kałduńska, J., Świniarska, B., Mijal, P., Stachowska, E. (2018). Dysbiotic factors and frequency of paintful defecation - result in Woodstock for future healthy study 2016-2017. 14 ${ }^{\text {th }}$ Warsaw International Medical Congress. Abstract book, $10^{\text {th }}-13^{\text {th }}$ May, Warsaw.

Skonieczna-Żydecka, K., Stachowska, E., Maciejewska, D., Ryterska, K., Palma, J., Czerwińska-Rogowska, M., Kaczmarczyk, M., Gudan, A., Mruk, H., Świniarska, B., Kałduńska, J., Stachowska, Z., Mijal, P., Mazur, T., Kupczyński, M., Marlicz, W. (2018). The digestive health among participants of the Woodstock Rock Festival in Poland-A cross-sectional survey. "International Journal of Environmet Reearch and Public Health", Vol. 15, Iss. 10. DOI: 10.3390/ijerph15102256.

Stachowska, E., Maciejewska, D., Ryterska, K., Baszuk, P., Skonieczna-Żydecka, K., Czerwińska-Rogowska, M., Palma, J., Gudan, A., Mruk, H., Wolska, A., Mazur, T., Paszkiewicz, D., Stachowska, Z., Stachowski, A., Marlicz, W. (2018). Abdominal pain and disturbed bowel movements are frequent among young people. A population based study in young participants of the Woodstock Rock Festival in Poland. "Journal of Gastrointestinal and Liver Diseases”, Vol. 27, No. 4. DOI: 10.15403/jgld.2014.1121.274.pol.

Węcławiak, A. (2016). „Performuj albo giń”. Przystanek Woodstock jako performans kulturowy. "Amor Fati”, nr 1(5).

Wood, E.H. (2009). Event marketing: Experience or outcome?. "Journal of Promotion Management”, Vol. 15, Iss. 1-2. DOI: 10.1080/10496490902892580.

Zarantonello, L., Schmitt, B.H. (2013). The impact of event marketing on brand equity. “International Journal of Advertising”, Vol. 32, Iss. 2. DOI: 10.2501/IJA-32-2-255-280.

Żyła, M. (2017). Przystanek Woodstock XXI wieku, czyli teatralizacja społeczeństwa i zmierzch subkultur. "Świat i Stowo”, nr 2(29). DOI: 10.5281/zenodo.12047.

DOI: $10.7862 /$ rz.2020.mmr.25

The text was submitted to the editorial office: October 2020.

The text was accepted for publication: December 2020. 